University of Nebraska - Lincoln

DigitalCommons@University of Nebraska - Lincoln

Publications, Agencies and Staff of the U.S.

Department of Commerce

U.S. Department of Commerce

$1-2009$

Do Monk Seals Exert Top-Down Pressure in Subphotic

Ecosystems?

Frank Parrish

Pacific Islands Fisheries Science Center, NOAA Fisheries

Follow this and additional works at: https://digitalcommons.unl.edu/usdeptcommercepub

Part of the Environmental Sciences Commons

Parrish, Frank, "Do Monk Seals Exert Top-Down Pressure in Subphotic Ecosystems?" (2009). Publications, Agencies and Staff of the U.S. Department of Commerce. 24.

https://digitalcommons.unl.edu/usdeptcommercepub/24

This Article is brought to you for free and open access by the U.S. Department of Commerce at DigitalCommons@University of Nebraska - Lincoln. It has been accepted for inclusion in Publications, Agencies and Staff of the U.S. Department of Commerce by an authorized administrator of DigitalCommons@University of Nebraska - Lincoln. 
MARINE MAMMAL SCIENCE, 25(1): 91-106 (January 2009)

No claim to original US government works

DOI: $10.1111 / \mathrm{j} .1748-7692.2008 .00245 . \mathrm{x}$

\title{
Do monk seals exert top-down pressure in subphotic ecosystems?
}

\author{
Frank A. PARRISH \\ Pacific Islands Fisheries Science Center, \\ NOAA Fisheries, \\ 2570 Dole Street, Honolulu, Hawaii 96822, U.S.A. \\ E-mail: frank.parrish@noaa.gov
}

\begin{abstract}
Patterns of subphotic fish assemblages on seamounts in the Northwestern Hawaiian Islands were identified and compared for potential structuring influences, including the bottom-up effects of regional oceanic productivity and top-down predation pressure exerted by visiting monk seals (Monachus schauinslandi). Patterns in fish size, density, and biomass were evaluated at the deep extreme (350-500 m) of the seals feeding range to avoid confounding effects of diverse shallow habitats (e.g., coral reefs). Fish number and size were used to calculate biomass density of the seamount fish assemblages that were then compared to the independent variables of summit depth, substrate type, relief, oceanic productivity, distance to seal colonies, and seal colony population. Only the variables of distance to seal colony and seal colony population were retained in a multiple regression model that explained $31 \%$ of the variance. Despite the presence of obvious regional differences in oceanic productivity, the overall patterns in the subphotic fish assemblages are better explained by the top-down hypothesis of predation pressure from monk seals.
\end{abstract}

Key words: deep water, marine fish, monk seals, seamounts, Monachus schauinslandi, foraging, predator control.

Regulation of marine community structure is usually divided into top-down or bottom-up influences. They are identified by patterns in assemblages that convey some generalization about where the bottlenecks are in the flow of energy through an ecosystem. Patterns that suggest the presence of structuring forces on a community can include things like irregularities in species composition, truncated size structure, or reduced biomass. Nutrient-limited phytoplankton production (Malone et al. 1996) and the food web that the plankton subsequently drives (Frederiksen et al. 2006) are examples of bottom-up control in ecosystems. The thinning of kelp beds by urchins (Halpern et al. 2006) and the structuring of otter populations by Killer Whales (Estes et al. 1998) are examples of top-down control. The last case is one of the few examples of top-down structuring concerning marine mammals. This scarcity may be in part a result of the difficulty of obtaining data on the prey community and defining the relevant boundaries of the forage grounds (Ciannelli et al. 2004). 
The Hawaiian monk seal is one of the few marine mammals where the foraging boundaries are clearly evident. The seals find their prey isolated on the summits of the Hawaiian ridge that rises from the abyss of the Pacific plate. The prey community of the monk seal has been thought to be bottom-up structured-a function of regional productivity. The Northwestern Hawaiian Islands (NWHI) spans the oceanic front that divides the productive northern ocean from the impoverished southern latitudes (Polovina et al. 2001). This frontal feature undergoes a southerly oscillation varying the regional exposure to productivity across latitudes. A number of models have been published that links beach counts of seals (Schmelzer 2000), seal body condition (Baker et al. 2007), and seal survivorship (Antonelis et al. 2003) to regional differences in oceanic productivity. They show the northern latitudes with the highest productivity, central latitudes with moderate productivity, and southern latitudes with the lowest productivity. These correlative analyses infer improved forage base as a function of sea surface productivity measured by satellite and were prompted by persistent differences in survivorship among monk seal colonies across the Northwestern Hawaiian Island Archipelago (Fig. 1). The seal colony with the poorest survivorship is the southernmost, French Frigate Shoals (FFS), which supports one-third of the archipelago's monk seals (Gilmartin et al. 1993, Gilmartin and Eberhardt 1995) and has exhibited a 60\% decline over the last two decades (Craig and Ragen 1999, Johanos and Baker 2000, Antonelis et al. 2006).

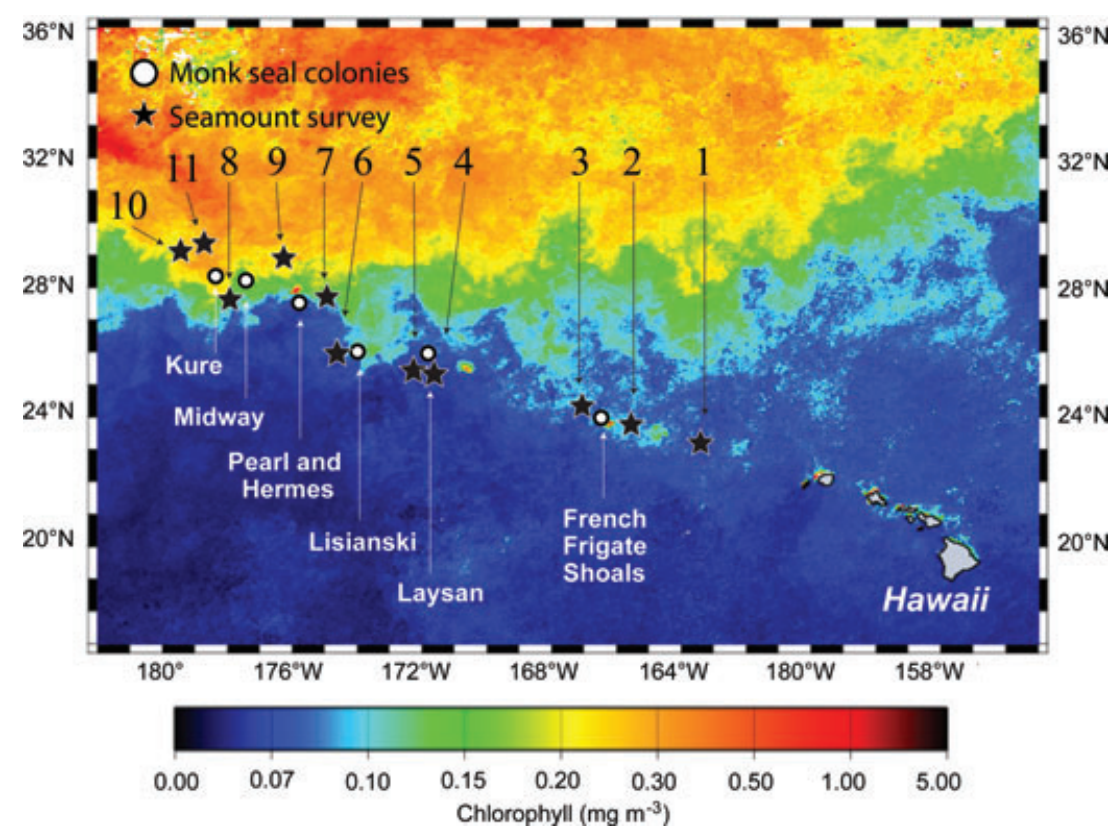

Figure 1. Satellite image (March) of sea surface phytoplankton around the Hawaiian Archipelago. The white dots and labels indicate the location of the six primary seal colonies and the black stars with numbers indicate the seamounts stations where subphotic fish were surveyed. 


\section{Monk Seal Prey Base}

Despite some good correlations with sea surface oceanic productivity, monk seals do not eat chlorophyll. Although the ecosystem link between oceanic productivity and the abundance of monk seal food is intuitive, it has never been specifically tracked or measured. Monk seals are foraging generalists that feed across the broad base of bottom-associated fish living on the slopes of the Hawaiian ridge. Early diet analyses looking at prey fragments from seal scats indicated that the seals ate primarily reef fish (Goodman-Lowe 1998). Based on these analyses, comparative surveys of reef fish were conducted at two atolls representing the high and low productivity extremes of the archipelago in hopes of detecting a pattern of higher fish abundance in productive northern latitudes (DeMartini et al. 2003). The results were inconclusive. More recent foraging studies indicate that the seals feed considerably deeper than previously thought, eating fish taxa from slope $(100-300 \mathrm{~m})$ and subphotic depths (300-500 m). Dive profiles from telemetry studies show deep-diving behavior at all the seal colonies throughout the island chain (Stewart et al. 2006). Findings from video cameras attached to foraging seals (Parrish et al. 2000, 2002), improved identification of prey remains in scat (Longnecker et al. 2006), and quantitative fatty acid analysis of the seals' $\operatorname{diet}^{1}$ all showed the seals feeding on deep-water fish species. Most recent are the results from Iverson $e t$ al. ${ }^{1}$ who assayed the blubber from monk seals $(n=234)$ at all the NWHI colonies and revealed that the seal's diet was mostly $(\sim 80 \%)$ slope fish with roughly a fourth coming from subphotic depths.

\section{Subphotic Venue for Model Comparison}

The seal's emphasis on deep prey is something of a paradigm shift and the subphotic feeding is of particular interest because it presents a unique opportunity to detect forces that structure the prey community. Studies using satellite-linked dive recorders show that seals at all colonies routinely commute to forage on the deep slopes of neighboring oceanic seamounts (Stewart et al. 2006). The numbers of dives decrease with depth but there is a segment of the seal population that visits the subphotic with dives recorded as deep as $500 \mathrm{~m}$. Seamounts that are closer to colonies of monk seals are subject to greater visitation; distant seamounts are subject to less. The seals exhibit regional fidelity in their foraging range with little overlap between the northern, central, and southern portions of the NWHI. Comparing prey assemblages in this "simpler" ecosystem, away from the complexity of shallow reefs, may better detect the forces that structure the prey community. Too deep for photosynthesis, the only productivity that subphotic depths receive is the organic rain from the production of surface waters (Graf 1989, Siegel and Deuer 1997). Seamounts in northern productive waters should exhibit more productivity than those at impoverished southern latitudes. Subphotic habitat is typically uniform open bottom composed of fossil carbonate, basalt/manganese crust, or a mix of the two. Infrequent patches of deep azooxanthellate corals occur in places exposed to intense flow (Parrish and Baco 2007). Because of the low habitat diversity and the fact that the resident fish community is adapted to living without light, they exhibit

\footnotetext{
${ }^{1}$ IVERSON, S., J. PiCHE AND W. BlanChard. Hawaiian monk seals and their prey in the Northwestern Hawaiian Islands: Assessing characteristics of prey species fatty acid signatures and consequences for estimating monk seal diet using quantitative fatty acid signature analysis (QFASA). U.S. Department of Commerce, NOAA-TM-NMFS-PIFSC-XXX. 146 pp. [unpublished]
} 
less affinity to habitat type than fish in the photic zone (Parrish 2006). Subphotic fish move slowly and occur in low densities, thus making them easy to survey. The cold temperatures $\left(7-12^{\circ} \mathrm{C}\right)$ and low productivity in the deep sea slows growth of fish and extends their longevity (Wilson and Kaufmann 1987). This environment makes for a stable fish community that should reflect the patterns of regional oceanic productivity. In contrast, any appreciable changes in the fish assemblage's rate of adult mortality (e.g., loss to predators) will quickly alter the community structure. The poor resilience of deep-sea fish means slow recovery from impacts (Koslow et al. 2000, Devine et al. 2006), which is an excellent situation to detect patterns in topdown pressure. Finally, there have been no NWHI fisheries operating at this depth that might compromise the ability to detect patterns in the community structure of the subphotic fish assemblage. The present study examines fish body size, density, and biomass of subphotic fish assemblages on seamounts throughout the NWHI and looks for bottom-up patterns attributable to oceanic productivity or top-down patterns that could be the result of foraging seals structuring the prey community.

\section{METHODS}

The first of three assumptions employed in this analysis is that monk seals are foraging generalists. All the available diet data discussed in the above section supports this. The seals target open bottom habitat where they are most successful at flushing prey but will eat whatever fish they find (Parrish et al. 2000, 2005). Because subphotic habitat is generally low-relief open bottom, the fish assemblage is exposed to capture when encountered by a monk seal. The second assumption is that monk seals are the only predators that reside within the shallow atolls that travel to neighboring seamounts to feed. Telemetry and tagging projects looking at the site fidelity of NWHI reef sharks (Lowe et al. 2006), jacks (Meyer et al. 2007a), and large bodied snappers (Meyer et al. 2007b) show no movement away from the isolation of their host reefs. The third assumption is that any variability introduced by a temporal change over the 4 yrs when the surveys were conducted did not undermine detecting effects of bottom-up or top-down patterns in community structure. Logistics of submersible operations prevented surveying all sites in $1 \mathrm{yr}$. An attempt was made to detect interannual effects by conducting a survey at one site over 3 yrs. Other points of uncertainty include the degree to which diet and movement data measured in recent years reflects where and what monk seals foraged on in the past. Temporal changes in the forage area, depth and prey are something as yet undetermined for monk seals.

\section{Survey of Subphotic Fish and Habitat}

Subphotic fish communities of 11 seamounts were visually surveyed at depths ranging from 350 to $500 \mathrm{~m}$ using the Pisces $I V$ and $V$ submersibles and the remote operated vehicle RCV-150. The seamount stations were numbered northbound 1 to 11 (Table 1 ). Their location represented the latitudinal range of productivity across transition zone chlorophyll front (TZCF) and was dispersed among the six primary monk seal colonies (Fig. 1). The southern region was surveyed in 1998, 2000, and 2001; the central region in 2002 and 2003; and the northern region in 2003. The same tract of bottom on the east French Frigate Shoals extension was surveyed in three different years $(1998,2000$, and 2001) and used as a reference site to look for interannual effects. The surveys endeavored to conduct four transects, $350 \mathrm{~m}, 400 \mathrm{~m}$, 
Table 1. Seamounts surveyed by the Pisces submersibles.

\begin{tabular}{|c|c|c|c|c|c|c|}
\hline \multicolumn{4}{|c|}{ Seamount } & \multicolumn{3}{|c|}{ Monk seal colonies } \\
\hline $\begin{array}{l}\text { Station } \\
\text { number }\end{array}$ & Name & Position & $\begin{array}{l}\text { Summit } \\
(\mathrm{m})\end{array}$ & Colony & Population $^{a}$ & $\begin{array}{l}\text { Distance } \\
(\mathrm{km})\end{array}$ \\
\hline \multirow[t]{2}{*}{1} & \multirow[t]{2}{*}{ WestPac } & \multirow[t]{2}{*}{$23^{\circ} 25^{\prime}, 162^{\circ} 84^{\prime}$} & \multirow[t]{2}{*}{287} & Nihoa $^{\mathrm{b}}$ & 20 & 83 \\
\hline & & & & Necker ${ }^{b}$ & 18 & 204 \\
\hline \multirow[t]{2}{*}{2} & \multirow[t]{2}{*}{ EFFS } & \multirow{2}{*}{$23^{\circ} 55^{\prime}, 165^{\circ} 23^{\prime}$} & \multirow[t]{2}{*}{350} & Necker & 18 & 83 \\
\hline & & & & FFS & 342 & 63 \\
\hline \multirow[t]{2}{*}{3} & \multirow[t]{2}{*}{ S. E. Brooks } & \multirow[t]{2}{*}{$23^{\circ} 58^{\prime}, 166^{\circ} 40^{\prime}$} & \multirow[t]{2}{*}{80} & FFS & 342 & 37 \\
\hline & & & & Laysan & 315 & 555 \\
\hline \multirow[t]{2}{*}{4} & \multirow[t]{2}{*}{ E. Northampton } & \multirow[t]{2}{*}{$25^{\circ} 19^{\prime}, 171^{\circ} 59^{\prime}$} & \multirow[t]{2}{*}{31} & Laysan & 315 & 42 \\
\hline & & & & Lisianski & 204 & 194 \\
\hline \multirow[t]{2}{*}{5} & \multirow[t]{2}{*}{ W. Northampton } & \multirow[t]{2}{*}{$25^{\circ} 33^{\prime}, 172^{\circ} 20^{\prime}$} & \multirow[t]{2}{*}{31} & Laysan & 315 & 55 \\
\hline & & & & Lisianski & 204 & 166 \\
\hline \multirow[t]{2}{*}{6} & \multirow[t]{2}{*}{ Bank 8} & \multirow[t]{2}{*}{$26^{\circ} 13^{\prime}, 174^{\circ} 30^{\prime}$} & \multirow[t]{2}{*}{55} & Lisianski & 204 & 56 \\
\hline & & & & $\begin{array}{l}\text { Pearl \& } \\
\text { Hermes }\end{array}$ & 239 & 222 \\
\hline \multirow[t]{2}{*}{7} & \multirow[t]{2}{*}{$\begin{array}{l}\text { E. Pearl \& } \\
\text { Hermes }\end{array}$} & \multirow[t]{2}{*}{$27^{\circ} 42^{\prime}, 175^{\circ} 36^{\prime}$} & \multirow[t]{2}{*}{109} & $\begin{array}{l}\text { Pearl \& } \\
\text { Hermes }\end{array}$ & 239 & 46 \\
\hline & & & & Midway & 71 & 83 \\
\hline \multirow[t]{2}{*}{8} & \multirow[t]{2}{*}{ Nero } & \multirow[t]{2}{*}{$27^{\circ} 56^{\prime}, 177^{\circ} 53^{\prime}$} & \multirow[t]{2}{*}{75} & Midway & 71 & 64 \\
\hline & & & & Kure & 129 & 74 \\
\hline 9 & Ladd & $28^{\circ} 30^{\prime}, 178^{\circ} 36^{\prime}$ & 64 & $\begin{array}{l}\text { Pearl \& } \\
\text { Hermes }\end{array}$ & 239 & 101 \\
\hline & & & & Midway & 71 & 46 \\
\hline 10 & Bank 10 & $28^{\circ} 55^{\prime}, 178^{\circ} 37^{\prime}$ & 194 & Midway & 71 & 166 \\
\hline & & & & Kure & 129 & 111 \\
\hline 11 & Bank 11 & $28^{\circ} 58^{\prime}, 179^{\circ} 32^{\prime}$ & 186 & Midway & 71 & 259 \\
\hline & & & & Kure & 129 & 75 \\
\hline
\end{tabular}

Listed are each seamount's station number, name, position, summit depth, population, and distance to nearby seal colonies. EFFS is east French Frigate Shoals.

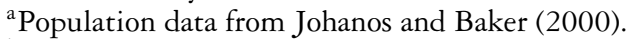

${ }^{\mathrm{b}} \mathrm{Nihoa}$ and Necker are rock islets with seals too few in number to be called seal colonies.

$450 \mathrm{~m}$, and $500 \mathrm{~m}$, run parallel to the contour of the seamount at each of the stations. The surveys employed a design that relied on a consecutive series of independent counts. Transects were divided into 5-min segments or "replicates" (Oksanen 2001). A minimum of six replicates per transect were made. With the sub/ROV cruising at $2 \mathrm{kns}$ a $\mathrm{m}$ above the bottom, all fish encountered were identified to the lowest taxa, counted and their body lengths were estimated using 5-cm categories. A laser reference scale was projected on the bottom within the view of the video cameras to assist the observers in their length estimations. To calculate numerical densities, fish counts were divided by the area surveyed (sub 3,600 $\mathrm{m}^{2}$, ROV $300 \mathrm{~m}^{2}$ ). Body lengths were used with length-weight coefficients and fish counts to derive the integrated measure of biomass density (Friedlander and Parrish 1998; PIFSC, unpublished data $\left.^{2}\right)$.

\footnotetext{
${ }^{2}$ Fish sampling log, May 2008, NOAA Fisheries, Pacific Islands Fisheries Science Center, 2570 Dole Street, Honolulu, HI 96822.
} 


\section{Independent Variables}

The independent variables were selected to distinguish patterns reflecting influences of ocean productivity or foraging pressure and to consider potential competing effects of seamount physiography and habitat. The chlorophyll $(\mathrm{Cbl} a)$ density from the subsurface layer of the chlorophyll maximum (Seki et al. 2002) and latitude are strongly correlated $(r=0.768 P<0.01)$, so latitude was used as a proxy for oceanic productivity (Fig. 1). The relative exposure of each seamount station to monk seal predation pressure was characterized using the population of seals at nearby colonies and the linear distance $(\mathrm{km})$ of the seamounts from neighboring seal colonies. The monk seal population data came from NMFS census effort, which conducts annual assessments of the seal colonies to count tag and resight seals (Johanos and Baker 2000). The distance to the seamount was the linear distance from the nearest edge of the reef at the seal colony to the seamount station. Summit depth was obtained for each station using nautical charts. Crude approximations of seamount areas taken from charts were found to correlate with summit depth $(r=0.86)$ suggesting that summit depth is a good general measure of seamount physiography. These independent variables are listed in Table 1 . To assess the habitat effect, the subphotic surveys recorded bottom substrate into three categories: fossil carbonate, sand, or basalt. Bottom relief was coded into low-relief $(<1 \mathrm{~m})$ flat bottom, moderate-relief $(1-3 \mathrm{~m})$ structurally configured bottom, and vertical habitat $(>3 \mathrm{~m})$.

\section{Analyses}

Accessibility afforded twice the sampling ( $n=541$ replicates) in the southern region (Brooks, EFFS, Westpac) than the central (Bank 8, east and west Northampton: $n=166)$ and the northern (PH, Ladd, Nero, Bank 10 and 11: $n=188$ ) regions of the archipelago. The smallest sample was 25 replicates for the most remote station (Seamount 11) and the largest was 284 replicates for the EFFS site that included $3 \mathrm{yr}$ of monitoring for temporal effects. Overall, the median sample for a station was 48 replicates. Fish too large to be considered seal prey $(>40 \mathrm{~cm})$, such as stingrays, made up $<1 \%$ of the data and were excluded from the analysis. The data were positively skewed. Parametric and nonparametric analyses were conducted and the parametric values were reported when there was agreement (Newton and Rudestam 1999). ANOVA were used to evaluate the numerical density and body lengths for the EFFS (Smt. no. 2) transect to test temporal effects and to test for differences among the seamounts. Biomass density was then used as an overall integrator of the fish assemblage in a stepwise multiple regression that evaluated all the independent variables. Care was taken to identify multicolinearity among the independent variables and evaluate the degree of autocorrelation with a Durbin-Watson index. The sample permitted the detection of small effects $\left(f^{2}=0.02\right)$ at a power of 0.80 with alpha set as 0.05 (Cohen 1988). Adjusted $r^{2}$ values were reported.

\section{RESULTS}

The surveys revealed a fish biomass density that was less than $5 \%$ of the fish communities documented at shallower depths of the region. The low density of fish found at subphotic depths resulted in high data variability. More than 18,000 fish were surveyed and they represented 42 taxa, the most common of which are listed in Table 2. Generally, the taxa were present across the latitudinal spread of 


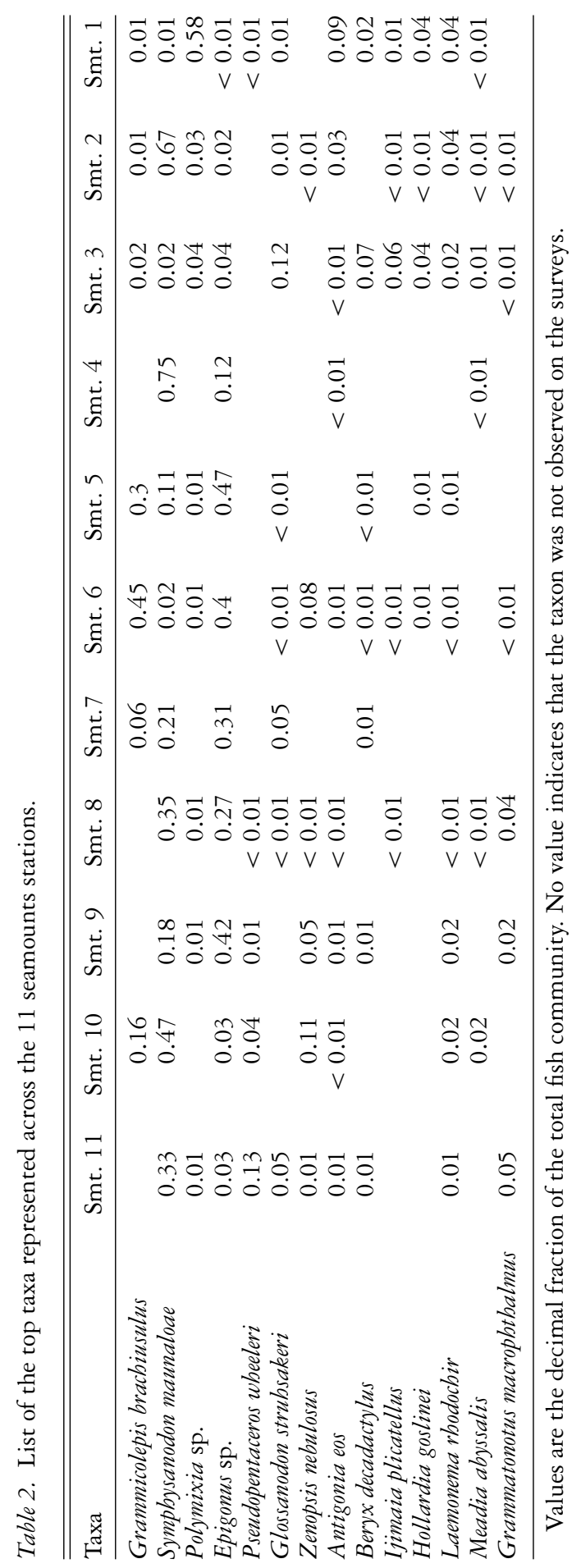




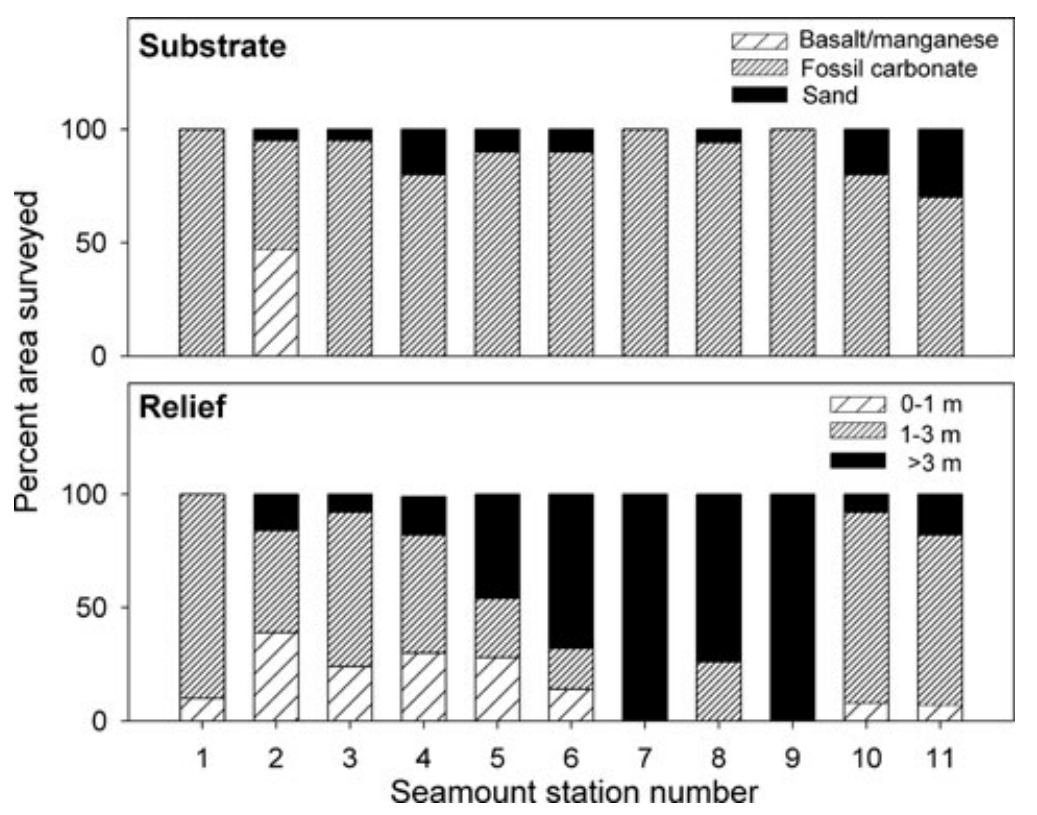

Figure 2. Percent composition of habitat variables substrate and relief type represented for each seamount station.

the seamount stations but they did vary in abundance. Percent substrate and relief types encountered on the surveys were plotted by seamount station and exhibited no pattern consistent with latitudinal effects (Fig. 2). Hard, flat white carbonate bottom with sand pockets was the norm. At EFFS (no. 2) some dark colored habitat was encountered and it may have been basalt or manganese encrusted carbonate. Steeper habitat was found more often on the central seamounts. The temporal comparison of the $3 \mathrm{yr}$ of data collected at the EFFS (no. 2) station showed no significant change in numerical density $(\mathrm{K}-\mathrm{W}=5.3, \mathrm{df}=2, P=0.07)$ or body length $(\mathrm{K}-\mathrm{W}=1.47$, $\mathrm{df}=2, P=0.475)$. Although not significant the $P$-value for density was close to the 0.05 level suggesting some sizable annual variation.

Comparing the 11 stations indicated significant differences in mean body length $(F=9.87, \mathrm{df}=10, P<0.001)$, numerical density $(F=7.5, \mathrm{df}=10, P<0.001)$, and biomass density $(F=7.12$, df $=10, P<0.001)$ (Fig. 3). The post hoc tests split the 11 seamount stations into groupings that did not conform to a latitudinal pattern. For biomass density, the southernmost seamount Westpac (no. 1) was grouped with northern seamounts (no. 8 and no. 11) at one extreme of the groupings and Brooks (no. 3) was at the other. A correlation matrix of fish size, density, and biomass showed no association with latitude, but some affinity for summit depth, seal population, and distance to nearby seal colonies (Table 3 ). The regression that assessed biomass density with all the independent variables retained only the two monk seal variables explaining a third of the overall variance in the fish community $\left(r^{2}=0.31, P<\right.$ 0.001). Latitude, the proxy for oceanic productivity, summit depth, and the two habitat variables (substrate and relief) explained no additional variance and were automatically dropped from the model. The $r^{2}$ value suggests that this is a moderate to large effect $\left(f^{2}=0.45\right)$ (Cohen 1988). Figure 4 shows plots of the biomass 

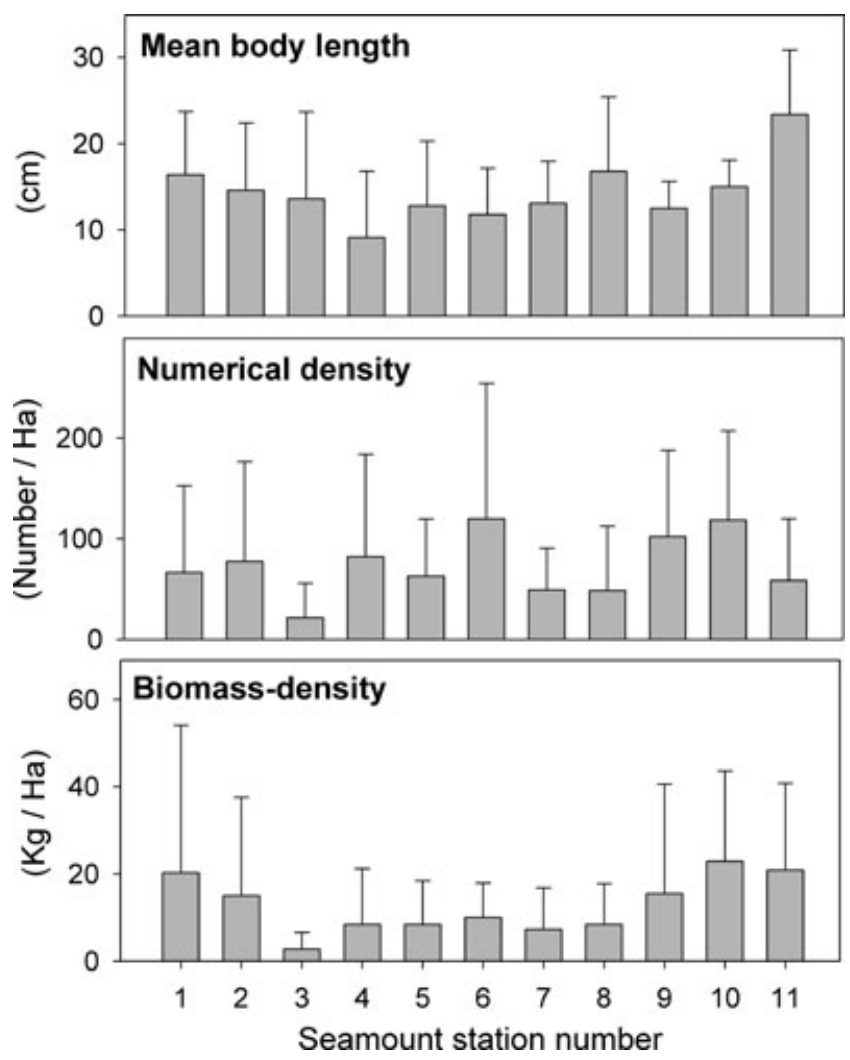

Figure 3. Mean (w/sd) size (body length), numerical density, and biomass density of the fish assemblage at the 11 seamounts.

density in relation to the primary effect of distance to monk seal colonies with the data presented as grand means. Latitude was also plotted with the grand means for comparison. When the analysis was repeated using resampled data to pull a uniform sample size across all seamounts, the same seal variables were selected by the model with a similar variance explained $\left(r^{2}=0.38\right)$.

Table 3. Correlation matrix of independent variables vs. mean numerical fish density, mean fish body length, and mean fish biomass density.

\begin{tabular}{lccc}
\hline \hline Independent variables & Mean density & Mean body length & Mean biomass \\
\hline Latitude (decimal degrees) & $\mathrm{ns}^{\mathrm{a}}$ & $\mathrm{ns}$ & $\mathrm{ns}$ \\
Summit depth (m) & $r=0.134$ & $r=0.06$ & $r=0.186$ \\
& $P<0.001$ & $P<0.049$ & $P<0.001$ \\
Distance to seal colonies $(\mathrm{km})$ & $r=0.142$ & $r=0.17$ & $r=0.222$ \\
& $P<0.001$ & $P<0.001$ & $P<0.001$ \\
Seal population (number of seals) & $\mathrm{ns}$ & $r=-0.147$ & $r=-0.146$ \\
& & $P<0.001$ & $P<0.001$ \\
\hline
\end{tabular}

${ }^{\mathrm{a}} \mathrm{ns}=$ not significant. 


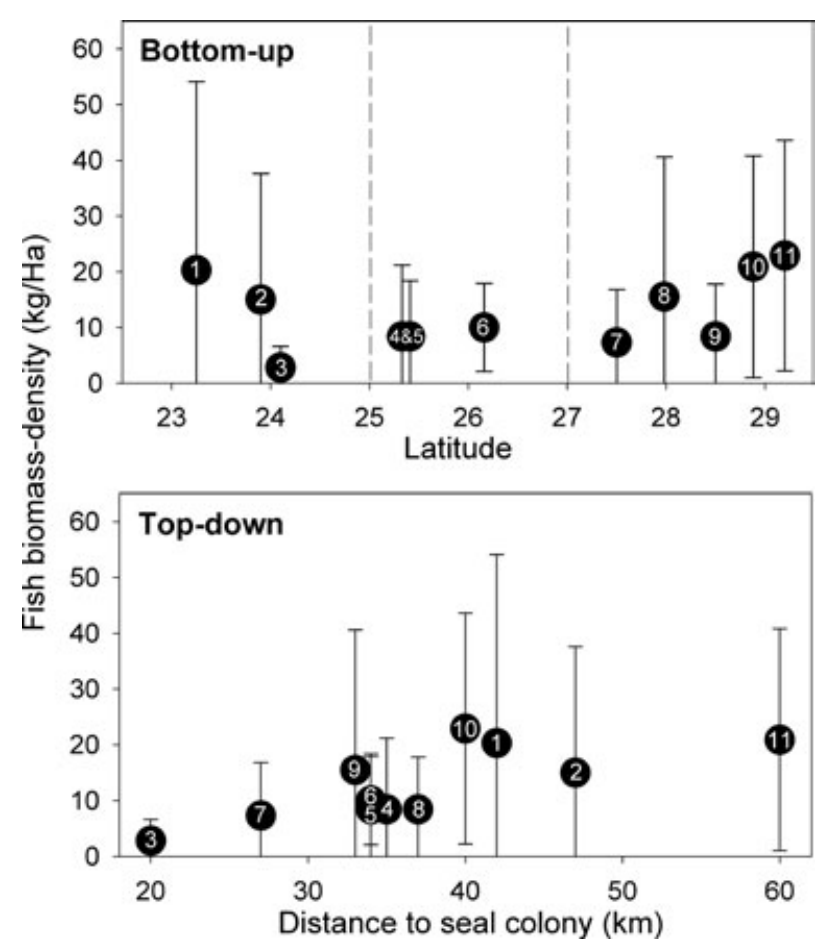

Figure 4. Bottom-up and top-down models of patterns in subphotic fish assemblages. The bottom-up model showing the poor correlation between latitude and the mean fish biomass density of the 11 seamount stations $(\mathrm{w} / \mathrm{sd})$. Dotted vertical lines indicate approximate boundaries between the south, central, and northern productivity regions. The top-down model showing seamount fish biomass density (w/sd) correlated with distance to neighboring monk seal colonies. Symbols are labeled with the seamount station numbers.

\section{DisCUSSION}

\section{Assumptions of the Analysis}

Exposed and slow moving, subphotic fish that are found by seals are likely to be captured. Table 4 indicates which of the subphotic fish have been identified in diet studies; more importantly, they include representatives from all the different evasion guilds (those that flee, those that remain motionless on the bottom, and those that look for shelter) suggesting that the seals are preying on the cross-section of the fish community. For this reason, biomass density should be a good measure of community structure in relation to monk seal foraging pressure.

Attributing the bulk of predation pressure to monk seals is a key assumption in this work. NWHI sharks and jacks have been identified as a force in shaping the biomass of shallower fish communities (Sudekum et al. 1991, Parrish and Boland 2004, DeMartini and Friedlander 2006, Myers et al. 2007). There is no data describing reef-related jacks and sharks feeding on subphotic fauna. The available mark recapture and movement studies in the NWHI show that these fish do not move from their atoll/bank (Lowe et al. 2006; Meyer et al. 2007a, b). There are likely transient 
Table 4. Subphotic fish families listed by evasion guild with some example photos.

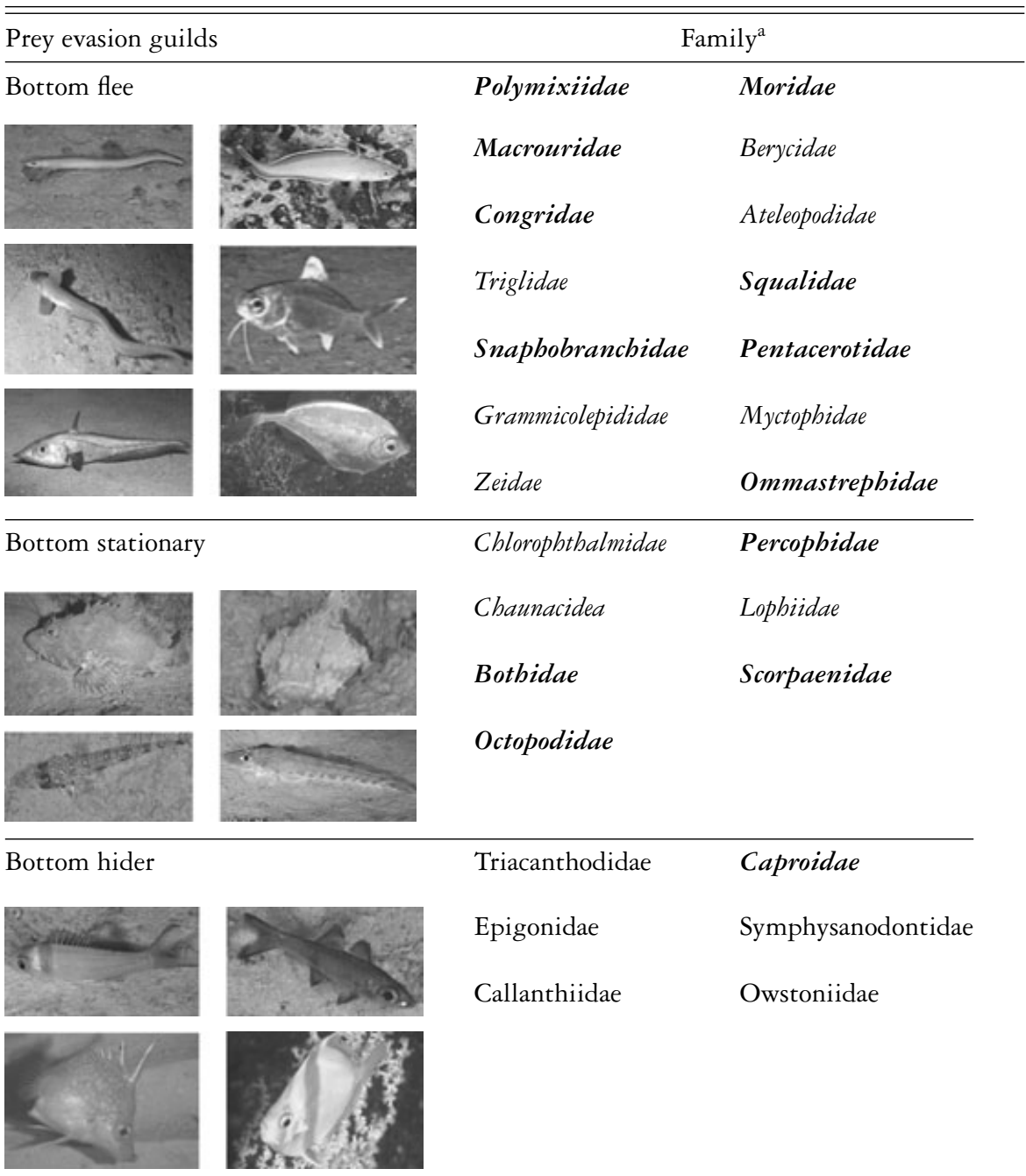

${ }^{a}$ Bold if confirmed in diet (Goodman-Lowe 1998, Parrish et al. 2002, Longnecker $e t$ al. 2006; Iverson et al. ${ }^{1}$ ).

subphotic or pelagic predators (Compagno 1984) that exert some foraging pressure on the fish communities of the subphotic slope, but there is no reason to think that there would be any particular regional pattern. Conceivably, there could be this type of predation pressure in conjunction with the oscillation of the transition zone chlorophyll front that might impose greater predation pressure on northern seamounts, but this pattern was not seen in the data.

There are no fishing effects to confound the patterns in these data. The NWHI are currently the focus of international attention because of the region's limited history of fishing and its recent protected status as the Papahānamokuākea Marine National 
Monument. Other than a summit trap fishery for lobster (DiNardo and Moffitt 2007), only a hook and line fishery operates for large-bodied snappers in mesophotic depths (100-300 m). Commonly called "bottomfish," these commercially sought taxa occur shallower than the subphotic fish assemblages. The cold water and low light environment of the subphotic serves as a lower boundary for the mesophotic community (Chave and Mundy 1994) making the presence of bottom fish at subphotic depths a rare exception.

\section{Influence of Independent Variables}

In the regression analysis, seamount physiography (summit depth) and habitat type failed to explain any sizable variance in the subphotic fish biomass. Physiography is a concern because seamounts are thought to affect "Taylor cones" or other mechanisms that could entrain nutrients and improve localized productivity (Boehlert and Genin 1987). Tests of these mechanisms suggest that seamount production is not derived locally but rather relies on the flow-through energy supply (Dower and Mackas 1996) that is modified by seamount physiography (Dower and Perry 2001). If true, the fish biomass of the seamounts should reflect the region's oceanic productivity and for the NWHI that means a gradient in fish biomass that increases with latitude. Even though summit depth was not retained by the regression model, it correlated positively with the fish variables (Table 3). This could be an artifact of deeper seamounts located farther from the seal colonies, thus overlapping the variance explained by the distance-to-seal-colony variable. It could also be that increased summit depth reduces the exposure of seamount fish assemblage to impacts from seal foraging pressure. Another possibility is that shallower seamounts support a community of reef predators that migrate down slope to feed exerting top-down pressure on the deeper fish community. Shallower summits have assemblages of reef jacks and sharks (Parrish and Boland 2004). Galapagos sharks have been recorded to visit subphotic depths, ${ }^{3}$ but reef jacks appear to stay within the upper $100 \mathrm{~m}$ (Meyer, ${ }^{3}$ Parrish et al. 2008). Such within-seamount pressure from mobile reef predators would explain the low biomass of fish at Brooks Bank (Smt. no. 3) but does not account for the moderately high biomass at the Northampton Seamounts (no. 4 and no. 5), Bank 8 (no. 6) and Nero (no. 8), which all are as shallow or shallower than Brooks Bank.

Substrate and relief are the primary benthic habitat variables of the subphotic ecosystem. Small patches of isolated deep coral are the only other habitat types, and coral colonization is limited to portions of the bottom subject to intense flow. Comparing fish abundance from coral patches to other similar tracts of bottom without coral did not show any significant difference (Parrish 2006). Seals searching the subphotic habitat encounter these coral patches, and there is evidence that they focus some of their activity around them or on the feature the corals colonize (Parrish et al. 2002). Even at this depth there are habitat effects such as sand fish being more common on sand or flat bottom and planktivores more common at sites of high flow, but the overall open nature of the bottom (few holes, caves, etc.) affords the foraging seal access to the cross-section of the fish community.

There was no dominant relationship between latitudes with higher oceanic productivity and fish communities with higher numerical density, larger mean body length, or higher overall biomass density. Latitude has been used as effective proxy

${ }^{3}$ Carl Meyer, Hawaii Institute of Marine Biology, University of Hawaii, P. O. Box 1346, Kaneohe, HI 96744, May 2008. 
for productivity in analyses addressing bottom-up forcing in pelagic communities (Ware and Thompson 2005). There was a general increase of biomass density with latitude (Fig. 2) but it was undermined by high fish values at two of the three seamounts surveyed in the impoverished southern region. These southern seamounts are closer to the main islands and thus had twice the sampling of other sites in the archipelago, so the data from Brooks (no. 3), EFFS (no. 2), and Westpac (no. 1) are hard to dismiss. The top-down model accounts for the pattern in the southern stations because two of the seamounts (EFFS and Westpac) are distant from surrounding seal colonies, reducing seal foraging pressure. The southernmost seamount (Westpac) with the highest fish values is particularly protected from predation pressure because there are few seals at the neighboring rookeries of Necker and Nihoa ( $n=38$ seals) and because of the considerable distance $(83-204 \mathrm{~km})$ from the rookeries and its deeper summit.

The depth to which the monk seals' foraging pressure extends is unknown. Studies using seal-mounted dive recorders have logged seals at over $500 \mathrm{~m}$ (Stewart et al. 2006). The deepest observation was made by Dr. Amy Baco-Taylor (Woods Hole Oceanographic Institute) at $536 \mathrm{~m}$ from the submersible Pisces V (Dingeman 2003). It is also unknown, whether subphotic fish have always been prey of the monk seal or whether the seals' feeding extended deeper over time to compensate for competition with shallow water fisheries or increasing interspecific competition with large predatory fish (Parrish et al. 2008). Current seal populations are likely much smaller than they were historically, so any historical effects of monk seal predation could have been much greater than they are today. The high variability in the subphotic fish data makes definitive conclusions difficult. The project's initial intent was to detect bottom-up patterns in oceanic productivity and instead a topdown model proved to be a better explanation. This finding may be a glimpse of the monk seals' predation impact on the adjacent seamount ecosystems and rare evidence that foraging by pinnipeds can be a principal structuring influence on their prey community.

\section{ACKNOWLEDGMENTS}

Submersible time provided by the NOAA Undersea Research Program/Hawaii Undersea Research Laboratory (HURL) with support from the NOAA Office of Ocean Exploration. Fellow observers included Raymond Boland, Richard Grigg, Bruce Mundy, Robert Moffitt, Walter Ikehara, Francis Oishi, and Sean Corson. Reviews were provided by Lyndon Wester, Charles Birkeland, Matt McGranaghan, Sheila Conant, Ross Sutherland, Charles Littnan, Bud Antonelis, Jeffrey Polovina, and two anonymous reviewers. Fish photos were provided by HURL.

\section{Literature Cited}

Antonelis, G. A., J. D. Baker and J. J. Polovina. 2003. Improved body condition of weaned Hawaiian Monk Seal pups associated with El Niño events: Potential benefits to an endangered species. Marine Mammal Science 19:590-598.

Antonelis, G. A., J. D. Baker, T. C. Johanos, R. C. Braun and A. Harting. 2006. A Hawaiian monk seal: Status and conservation issues. Atoll Research Bulletin 543:75101.

Baker, J. D., J. J. Polovina And E. A. Howell. 2007. Effect of variable oceanic productivity on the survival of an upper trophic predator, the Hawaiian monk seal, Monachus schauinslandi. Marine Ecology Progress Series 346:277-283. 
Boehlert, G. W., AND A. Genin. 1987. A review of the effects of seamounts on biological processes. AGU Geophysical Monographs 43:319-334.

Craig, M. P., and T. J. RAGEN. 1999. Body size, survival, and decline of juvenile Hawaiian monk seals, Monachus schauinslandi. Marine Mammal Science 15:786-809.

Chave, E. H., And B. C. Mundy. 1994. Deep-sea fish of the Hawaiian Archipelago, Cross Seamount, and Johnston Atoll. Pacific Science 48:367-409.

Ciannelli, L., B. Robson, R. Francis, K. Aydin and R. Brodeur. 2004. Boundaries of open marine ecosystems: An application to the Pribilof Archipelago, southeast Bearing Sea. Ecological Applications 14:942-953.

COHEN, J. 1988. Statistical power analysis for the behavioral sciences. Lawrence Erlbaum Associates, Hillsdale, NJ.

Compagno, L. J. V. 1984. Sharks of the world. An annotated and illustrated catalogue of shark species known to date. FAO Fisheries Synopsis 125:241-655.

DeMartini, E. E., F. A. Parrish and R. C. Boland. 2003. Comprehensive (1992/93 19952000) evaluation of shallow reef fish populations at French Frigate Shoals and Midway Atoll, Northwestern Hawaiian Islands, with results of methods-calibration study for bridging past and future surveys. NOAA Technical Memorandum NMFS-SWFSC-HO. $58 \mathrm{pp}$.

DeMartini, E. E., AND A. M. Friedlander. 2006. Predation, endemism, and related processes structuring shallow-water reef fish assemblages of the NWHI. Atoll Research Bulletin 543:237-256

Devine, J. A., K. D. Baker And R. L. Haedrich. 2006. Fisheries deep-sea fishes qualify as endangered. Nature 439:29.

Dinardo, G. T., AND R. B. Moffitt. 2007. The Northwestern Hawaiian Islands lobster fishery: A targeted slipper lobster fishery. Pages 243-261 in K. L. Lavalli and E. Spanier, eds. The biology and fisheries of the slipper lobster. CRC Press, Boca Raton, FL.

Dingeman, R. 2003. Voyage yields some deep-sea delights. Honolulu Advertiser, 7 November 2003. Available at http://the.honoluluadvertiser.com/article/2003/Nov/07/ $\ln / \ln 03$ a.html.

Dower, J. F., AND D. L. MACKAS. 1996. "Seamount effects" in the zooplankton community near Cobb Seamount. Deep-Sea Research I, 43:837-858.

Dower, J. F., AND R. I. PerRy. 2001. High abundance of larval rockfish over Cobb Seamount, an isolated seamount in the Northeast Pacific. Fisheries Oceanography 10:268-274.

Estes, J. A., M. T. Tinker, T. M. Williams And D. F. DoAk. 1998. Killer whale predation on sea otters linking oceanic and nearshore ecosystems. Science 282:473-476.

Frederiksen, M., M. Edwards, A. J. Richardson, N. C. Halliday and S. Wanless. 2006. From plankton to top predators: Bottom-up control of a marine food web across four trophic levels. Journal of Animal Ecology 75:1259-1268.

Friedlander, A. M., AND J. D. PARrish. 1998. Habitat characteristics affecting fish assemblages on a Hawaiian coral reef. Journal of Experimental Marine Biology and Ecology 224:1-30.

Gilmartin, W. G., T. C. JohanOS AND L. L Eberhardt. 1993. Survival rates for the Hawaiian monk seal (Monachus schauinslandi). Marine Mammal Science 9:407-420.

Gilmartin, W. G., AND L. L. EberhardT. 1995. Status of the Hawaiian monk seal (Monachus schauinslandi) population. Canadian Journal of Zoology 73:1185-1190.

Goodman-Lowe, G. 1998. Diet of Hawaiian monk seal (Monachus schauinslandi) from the Northwestern Hawaiian Islands during 1991-1994. Marine Biology 132:535-546.

GrAF, G. 1989. Benthic-pelagic coupling in a deep sea benthic community. Nature 341:437439.

Halpern, B. S., K. Cottenie and B. R. Broitman. 2006. Strong top-down control in Southern California kelp forest ecosystems. Science 312:1230-1232.

Johanos, T. C., AND J. D. BAKer. 2000. The Hawaiian monk seal in the Northwestern Hawaiian Islands. U.S. Department of Commerce, NOAA Technical Memorandum NMFS-SWFSC-292. 125 pp. 
Koslow, J. A., G. W. Boehlert, J. D. M. Gordon, R. L. Haedrich, P. Lorance and N. PARIN. 2000. Continental slope and deep-sea fisheries implications for a fragile ecosystem. ICES Journal of Marine Science 57:548-557.

Longnecker, K., R. A. Dollar And M. K. CAHOON. 2006. Increasing taxonomic resolution in dietary analysis of the Hawaiian monk seal. Atoll Research Bulletin 543:101-113.

Lowe, C. G., B. M. WeTherbee AND C. G. MeYer. 2006. Using acoustic telemetry monitoring technique to quantify movement patterns and site fidelity of shark and giant trevally around French Frigate Shoals and Midway Atoll. Atoll Research Bulletin 543:281304.

Malone, T. L., D. J. Conley, T. R. Fisher, P. M. Gilbert, L. W. Harding and K. G. SELLNER. 1996. Scales of nutrient-limited phytoplankton productivity in Chesapeake Bay. Estuaries 19:371-385.

Meyer, C. G., K. N. Holland and Y. P. Papastamatiou. 2007 a. Seasonal and diel movements of giant trevally Cranax ignobilis at remote Hawaiian atolls: Implications for the design of marine protected areas. Marine Ecology Progress Series 333:13-25.

Meyer, C. G., Y. P. Papastamatiou and K. N. Holland. 2007b. Seasonal, diel, and tidal movements of green jobfish (Aprion virscens, Lutjanidae) at remote Hawaiian atolls: Implications for marine protected area design. Marine Biology 151:2133-2143.

Myers, R. A., J. K. Baum, T. D. Shepherd, S. P. Powers and C. H. Peterson. 2007. Cascading effects of the loss of apex predatory sharks from a coastal ocean. Science 315:1846-1850.

Newton, R. R., AND K. E. Rudestam. 1999. Your statistical consultant. Sage, London, UK.

OKSANEN, L. 2001. Logic of experiments in ecology: Is pseudoreplication a pseudoissue? Oikos 94:27-38.

Parrish, F. A., M. P. Craig, T. J. Ragen, G. J. Marshall and B. M. Buhleier. 2000. Identifying diurnal foraging habitat of endangered Hawaiian monk seals using a sealmounted video camera. Marine Mammal Science 16:392-412.

Parrish, F. A., K. Abernathy, G. J. Marshall and B. M. Buhleier. 2002. Hawaiian monk seals (Monachus schauinslandi) foraging in deep-water coral beds. Marine Mammal Science 18:244-258.

PARrish, F. A., AND R. C. Boland. 2004. Habitat and reef-fish assemblages of banks in the Northwestern Hawaiian Islands. Marine Biology 144:1065-1073.

Parrish, F. A., G. J. Marshall, C. L. Littnan, M. Heithaus, S. Canja, B. Becker, R. Braun AND G. A. ANTONELIs. 2005. Foraging of juvenile monk seals at French Frigate Shoals, Hawaii. Marine Mammal Science 21:93-107.

PArrish, F. A. 2006. Precious corals and subphtoic fish assemblages. Atoll Research Bulletin 543:425-438.

PARrish, F. A., AND A. R. BACO. 2007. State of deep coral ecosystems in the U.S. Pacific Islands Region: Hawaii and the U.S. Pacific Territories. Pages 155-194 in S. E. Lumsden, T. F. Hourigan, A. W. Bruckner and Gabrielle Dorr, eds. The state of deep coral ecosystems of the United States: 2007. NOAA Technical Memorandum CRCP-3, Silver Spring, MD

Parrish, F. A., G. J. Marshall, B. Buhleier and G. A. Antonelis. 2008. Foraging interaction between monk seals and large predatory fish in the Northwestern Hawaiian Islands. Endangered Species Research 4:299-308.

Polovina, J. J., E. Howell, D. R. Kobayashi And M. P. SeKi. 2001. The transition zone chlorophyll front. A dynamic global feature defining migration and forage habitat for marine resources. Progress in Oceanography 49:469-483.

Schmelzer, I. 2000. Seals and seascapes: Covariation in Hawaiian monk seal subpopulations and the oceanic landscapes of the Hawaiian Archipelago. Journal of Biogeography 27:907-914.

Seki, M. P., J. J. Polovina, D. R. Kobayashi, R. R. Bidigare and G. T. Mitchum. 2002. An oceanographic characterization of swordfish (Xiphias gladius) longline fishing grounds in the springtime subtropical North Pacific. Fisheries Oceanography 11:251-266. 
Siegel, D. A., AND W. G. Deuer. 1997. Trajectories of sinking particles in the Sargasso Sea: Modeling statistical funnels above deep ocean sediment traps. Deep-Sea Research I 44:1519-1541.

Stewart, B. S., G. A. Antonelis, J. D. Baker and P. K. Yochem. 2006. Foraging Biogeography of Hawaiian monk seals in the Northwestern Hawaiian Islands. Atoll Research Bulletin 543:131-146.

Sudekum, A. E., J. D. Parrish, R. L. Radtke and S. Ralston. 1991. Life history and ecology of large jacks in undisturbed, shallow, oceanic communities. Fishery Bulletin 89:493-513.

Ware, D., And R. Thomson. 2005. Bottom-up ecosystem trophic dynamics determine fish production in the Northeast Pacific. Science 308:1280-1284.

WilsON, R. R., AND R. S. KaUfmann. 1987. Seamount biota and biogeography. AGU Geophysical Monograph 43:355-377.

Received: 12 September 2007 Accepted: 7 July 2008 